\title{
Effect of Compost Amendments on Disease Severity and Yield of Tomato in Conventional and Organic Production Systems
}

\author{
P. A. Abbasi, J. Al-Dahmani, F. Sahin, H. A. J. Hoitink, and S. A. Miller, Department of Plant Pathology, The \\ Ohio State University, Ohio Agricultural Research and Development Center, Wooster 44691
}

\begin{abstract}
Abbasi, P. A., Al-Dahmani, J., Sahin, F., Hoitink, H. A. J., and Miller, S. A. 2002. Effect of compost amendments on disease severity and yield of tomato in organic and conventional production systems. Plant Dis. 86: 156-161.

Field trials were conducted over 2 years to assess the effects of compost amendments on disease development in organic and conventional processing tomato (Lycopersicon esculentum L.) production systems. The incidence of anthracnose fruit rot was reduced in organic tomato plots amended with a high rate of composted cannery wastes compared with the incidence in nonamended control plots in 1998 when disease incidence was high. Marketable yield was increased by $33 \%$ in compost-amended organic plots. Plots amended with a high compost rate had more ripe fruit than the nonamended control. The incidence of anthracnose and of total disease on fruit was less on the cultivar $\mathrm{OH} 8245$ than on Peto 696. Total fruit yield of OH 8245 but not Peto 696 in organic plots was increased by amendment with composted cannery wastes. In conventional tomato production, composted yard wastes increased disease severity on foliage both years but reduced bacterial spot incidence on fruit in 1997, when disease pressure was high. The incidence of anthracnose was not affected by composted yard wastes. Marketable and total fruit yields of Peto 696 were not increased in compost-amended conventional plots. The plant activator Actigard reduced foliar disease severity and the incidence of bacterial spot and anthracnose on fruit, while increasing yield of marketable fruit.
\end{abstract}

Additional keywords: benzothiadiazole, biological control, compost-induced control of foliar plant diseases, compost-induced systemic resistance, organic soil amendments

Foliar and fruit diseases of tomato ( $L y$ copersicon esculentum L.), such as early blight (Alternaria solani), Septoria leaf spot (Septoria lycopersici), anthracnose (Colletotrichum coccodes), bacterial spot (Xanthomonas vesicatoria and X. axonopodis pv. vesicatoria), and bacterial speck (Pseudomonas syringae pv. tomato), can severely curtail production of this crop under climatic conditions that typically occur in Ohio and other Midwestern states. Although commercial fungicides generally provide effective control of most fungal pathogens causing foliar diseases of tomato, multiple applications are usually required (9). Bacterial diseases are man-

Corresponding author: S. A. Miller

E-mail: miller.769@osu.edu

This research was supported by a grant from the USDA North Central Sustainable Agriculture Research and Education Program and by state and federal funds appropriated to The Ohio State University and the Ohio Agricultural Research and Development Center, Wooster.

Current address of P. A. Abbasi: Agriculture and Agri-Food Canada, SCPFRC, 1391 Sandford Street, London, Ontario, N5V 4T3 Canada.

Accepted for publication 8 October 2001.

Publication no. D-2001-1207-02R

(C) 2002 The American Phytopathological Society aged primarily with fixed copper compounds, although control is generally inadequate due to the prevalence of copper-resistant strains and weather conditions that often favor bacterial diseases in the field $(2,29,31)$. Both fungal and bacterial diseases are difficult to manage in organic tomatoes in Midwestern states, often causing significant losses in yield and quality (S. Miller, unpublished data). High levels of resistance to bacterial spot, early blight, Septoria leaf spot, and anthracnose are not available in processing tomato cultivars, and fungicide use on organic farms is limited to certain copperand sulfur-based compounds. In both production systems, additional disease management strategies are needed to reduce economic losses caused by these diseases.

Organic farmers often use composts as soil amendments, particularly in intensive vegetable production systems, to improve soil fertility and quality and sustain productivity $(6,23,38)$. Composts improve biological, chemical, and physical properties of amended soils $(7,19,24,26)$. Furthermore, composts incorporated into soil or planting mixes can provide effective biological control of diseases caused by soilborne plant pathogens $(4,8,13-$ $16,20,22,28,32,37)$. They also may reduce the severity of diseases caused by foliar plant pathogens $(25,36)$. It was shown recently that composts may improve the ability of plants to resist diseases caused by root as well as foliar pathogens by inducing systemic resistance in plants $(12,39,40)$. The components of composts responsible for this induced activity may be biological or chemical in nature (39). Resistance induced by plant activators $(10,30,34)$ such as Actigard (acibenzolar-smethyl; Syngenta Crop Protection, Greensboro, NC) has been shown to be as effective as fixed copper sprays in reducing the incidence and severity of bacterial spot and speck in both fresh market and processing tomatoes (21).

The objective of this study was to determine the effects of composts on the incidence of fungal and bacterial diseases and fruit yield in conventional and organic tomato production systems. A preliminary report on a portion of this work was published previously (1).

\section{MATERIALS AND METHODS}

Plant materials and transplant mixes. Seedlings of the tomato processing cultivars Peto 696 (Petoseed Co., Inc., Saticoy, $\mathrm{CA}$ ) and $\mathrm{OH} 8245$ (Terra Industries Inc. Sioux City, IA) were produced in greenhouses according to standard procedures (27) in a sphagnum peat planting mix (BACCTO high porosity planting mix; Michigan Peat Co, Houston, TX) or a composted pine bark plug mix fortified with the biocontrol agents Trichoderma hamatum 382 and Chryseobacterium gleum 299 (formerly Flavobacterium balustinum 299) received from Earthgro, Inc. (Lebanon, CT).

Experimental design. Plots were established in a split-split plot design with four replicates per treatment. In both organic and conventional tomato production systems, compost treatments were assigned to main plots and planting mix was a treatment split assigned to subplots. In the organic trial, sub-subplots were tomato cultivars whereas, in conventional trials, spray treatments were sub-subplots.

Composts. Composted yard wastes prepared as described previously (11) were obtained from Kurtz Bros. Inc. (Independence, $\mathrm{OH})$. Composted cannery waste was produced in windrows at Hirzel Farms (Luckey, OH) from tomato processing byproducts $(40 \%)$, duck manure $(20 \%)$, municipal yard waste $(20 \%)$, and reed canary grass straw $(20 \%)$, all on a volume basis. The stability of all composts used in this work determined by respirometry ex- 
ceeded $0.5 \mathrm{~g}$ of $\mathrm{O}_{2}$ uptake $\mathrm{kg}^{-1}$ dry weight of volatile solids $\mathrm{h}^{-1}$, which is well below the threshold of phytotoxicity associated with immature composts (18). Chemical analyses of the composts used in this work are given in Table 1. Composts were applied to the main plots with a manure spreader and tilled into soil to a depth of 5 to $8 \mathrm{~cm}$.

Organic tomato production. The organic tomato production trial was conducted at Hirzel Farms, Luckey, $\mathrm{OH}$, on certified organic fields in a 5-year rotation plan. Composted cannery waste was applied to the main plots during November 1996 at rates of 0,12 , and $24 \mathrm{t} / \mathrm{ha}$ or in November 1997 at 0,15, and $30 \mathrm{t} / \mathrm{ha}$, all on a dry weight basis. Seedlings were produced at Hirzel Farms as described above. Seedlings of tomato 'Peto 696' and ' $\mathrm{OH}$ 8245 ' were planted $45 \mathrm{~cm}$ apart on raised beds in double, staggered rows (40 plants/treatment). Supplemental irrigation was not applied. All fruit from five plants in the middle of each plot were harvested on the same day, sorted, and graded. Categories were marketable (healthy red) fruit, healthy immature fruit, anthracnose (on ripe fruit), bacterial spot or speck on ripe fruit, bacterial spot or speck on immature fruit, and other nonspecified fruit rots. The incidence of bacterial spot, bacterial speck, and anthracnose on fruit was calculated based on the weight of fruit in each category.

Conventional tomato production. The conventional processing tomato field trial was carried out at OSU/OARDC in Wooster, $\mathrm{OH}$ in 1997 and 1998 utilizing composted yard wastes. Tomato seedlings were produced in a greenhouse in the biocontrol agent-fortified composted pine barkamended mix or the standard peat mix described above. Composted yard wastes were applied to the main plots in April as described above at the rates of 0,25 , and $50 \mathrm{t} / \mathrm{ha}$ (1997) and 0,38 , and $74 \mathrm{t} / \mathrm{ha}$ (1998), all on a dry weight basis. Control plots (0 t/ha compost) were treated with ammonium nitrate, potassium phosphate, and treble super phosphate to raise the N, $\mathrm{P}$, and $\mathrm{K}$ concentrations to 85,57 , and 274 $\mathrm{kg} / \mathrm{ha}$, respectively, according to recommended soil fertility guidelines for tomato (27). The low compost loading rate supplied equivalent concentrations of available N, P, and K. Tomato cv. Peto 696 was used in all conventional plots. In early June, seedlings were transplanted $30 \mathrm{~cm}$ apart in single rows on raised beds on $1.5-\mathrm{m}$ centers (15 plants/treatment). Actigard at $35 \mathrm{~g}$ a.i./ha was applied as a spray treatment at 7- to 10-day intervals throughout the growing season. Control plots were sprayed with water. A total of 12 applications were made each year. All plots were inoculated with $X$. vesicatoria twice each season, first during the last week of June and again during the last week of July, by spraying a mixture of strains $(544,560$, and 572) at the rate of $10^{8} \mathrm{CFU} \mathrm{ml}^{-1}$. High humidity and leaf wetness were maintained by sprinkler irrigation $24 \mathrm{~h}$ before and $48 \mathrm{~h}$

Table 1. Characteristics of composts used as soil amendments

\begin{tabular}{|c|c|c|c|c|}
\hline \multirow[b]{2}{*}{ Compost amendment } & \multirow[b]{2}{*}{ Moisture content $(\%)$} & \multicolumn{3}{|c|}{$\%$ Total $^{\mathrm{z}}$} \\
\hline & & $\mathbf{N}$ & $\mathbf{P}$ & $\mathbf{K}$ \\
\hline Composted yard wastes & 55.0 & 1.7 & 0.7 & 1.1 \\
\hline Composted cannery wastes & 50.0 & 1.6 & 1.3 & 0.6 \\
\hline
\end{tabular}

${ }^{\mathrm{z}}$ Total nitrogen, $\mathrm{P}_{2} \mathrm{O}_{5}$, and $\mathrm{K}_{2} \mathrm{O}$ on a dry weight basis. after inoculation. Other foliar and fruit diseases, including early blight, Septoria leaf spot, and anthracnose, appeared naturally in the plots. All 15 plants/ treatment were assessed for total foliar disease three times during the season (19 and 31 August and 12 September in 1997; 7, 17, and 27 August in 1998) using a modified Horsfall-Barratt scale $(1=$ no disease to $12=100 \%$ disease; 17$)$. Due to the difficulties inherent in visually differentiating foliar diseases, two of which (bacterial leaf spot and Septoria leaf spot) cause defoliation, no attempt was made to rate the diseases separately. The area under the disease progress curve (AUDPC) was calculated using the midpoint of each Horsfall-Barratt rating (percent foliar disease). All fruit from five plants from the middle of each plot were harvested, sorted, and graded. Fruit categories and calculation of disease incidence were as described for the organic production trials. In 1997, fruit were harvested over a 2- to 3-week period, when approximately $80 \%$ were ripe in individual plots. In 1998, fruit were harvested at one time, when fruit in control plots not amended with compost were approximately $70 \%$ ripe.

Nutrient analyses in foliage. At early flowering, the most recent fully expanded tomato leaves from 10 plants (one from each plant) were harvested from organic and conventional plots to determine the concentrations of essential macro and micro plant nutrients in the foliage through analyses performed at the REAL laboratory, The Ohio State University, Wooster.

Statistical analyses. All statistical analyses were performed using SAS statistical software (ver. 8.0; SAS Institute Inc., Cary, NC). Data on percent bacterial disease and anthracnose on fruit in the organic tomato production trial were trans-

Table 2. Analyses of variance (ANOVA) of percent bacterial spot or speck, anthracnose, and total disease on fruit, marketable and total yield, and percent total ripe fruit in organic tomato production during 1997 and $1998^{x}$

\begin{tabular}{|c|c|c|c|c|c|c|c|}
\hline \multirow[b]{2}{*}{ Source } & \multirow[b]{2}{*}{ df } & \multicolumn{6}{|c|}{ Mean squares $^{y}$} \\
\hline & & $\begin{array}{c}\text { Spot or speck } \\
(\%)^{\mathrm{z}}\end{array}$ & $\begin{array}{c}\text { Anthracnose } \\
(\%)^{\mathrm{z}}\end{array}$ & $\begin{array}{l}\text { Total diseased } \\
\text { fruit }(\%)\end{array}$ & $\begin{array}{c}\text { Marketable } \\
\text { yield }\end{array}$ & $\begin{array}{l}\text { Total } \\
\text { yield }\end{array}$ & $\begin{array}{c}\text { Total ripe fruit } \\
(\%)\end{array}$ \\
\hline Year & 1 & $24.5^{* *}$ & $73.3 * *$ & $4,404.0^{* *}$ & $5,680.3 * *$ & $9,981.5^{* *}$ & $2,362.5^{* *}$ \\
\hline Block (year) & 6 & 1.4 & 1.4 & 139.9 & 4.4 & 23.5 & 34.3 \\
\hline Compost & 2 & 0.0 & 0.5 & 53.9 & $1,686.0 * *$ & $1,096.3 *$ & $96.5^{*}$ \\
\hline Year $\times$ compost & 2 & 0.6 & $1.5^{+}$ & 37.6 & 102.6 & 201.1 & 31.7 \\
\hline Block $\times$ compost (year) & 12 & 0.7 & 0.5 & 46.7 & 97.2 & 169.3 & 13.8 \\
\hline Planting mix & 1 & 0.2 & 0.8 & 126.9 & 4.5 & 0.3 & 100.5 \\
\hline Year $\times$ planting mix & 1 & $4.1^{*}$ & 0.8 & 34.4 & 83.6 & 94.5 & 6.3 \\
\hline Compost $\times$ planting mix & 2 & 0.2 & 0.9 & 24.1 & 58.7 & $226.0^{*}$ & 12.7 \\
\hline Block $\times$ planting mix (year) & 6 & 0.3 & 0.4 & 83.9 & 131.7 & 26.4 & 21.5 \\
\hline Cultivar & 1 & $2.1 *$ & 1.8 & $316.1 * *$ & 3.6 & 269.8 & $353.2 * *$ \\
\hline Year $\times$ cultivar & 1 & 0.2 & $8.9 *$ & $448.3 * *$ & $961.5^{*}$ & 252.2 & $188.5^{*}$ \\
\hline Compost $\times$ cultivar & 2 & 0.6 & 1.7 & 52.6 & 31.3 & $610.6 *$ & 39.6 \\
\hline Planting mix $\times$ cultivar & 1 & 0.5 & 0.1 & 8.4 & 8.8 & 230.8 & 15.7 \\
\hline Compost $\times$ planting mix $\times$ cultivar & 2 & 0.1 & 0.3 & 50.3 & 211.0 & 125.8 & 16.4 \\
\hline Error & 55 & 0.4 & 0.8 & 43.3 & 115.2 & 190.9 & 20.4 \\
\hline Coefficient of variation & $\ldots$ & 250.6 & 65.6 & 52.4 & 22.8 & 20.2 & 5.0 \\
\hline
\end{tabular}

${ }^{x}$ ANOVA was performed on combined 1997 and 1998 data.

$\mathrm{y}+, *$, and $* *$ represent significant effects at the $P=0.1, P=0.05$, and $P=0.01$ level of probability, respectively.

${ }^{\mathrm{z}}$ Analysis was performed on transformed data. 

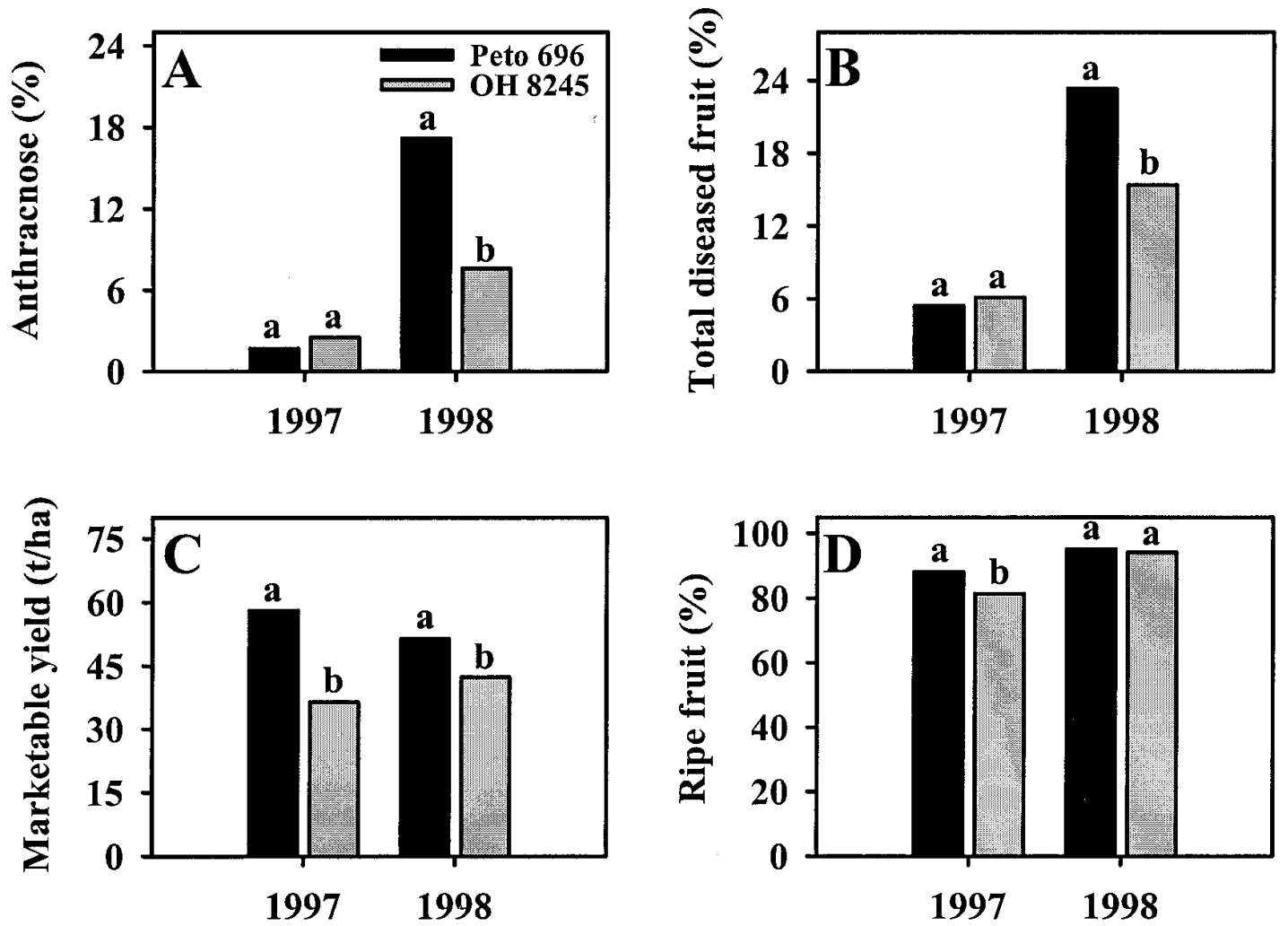

Fig. 1. Main effects of cultivar on A, the incidence of anthracnose (\% of total fruit), B, total disease (bacterial speck or spot and anthracnose) on fruit, C, marketable yield of fruit (total healthy fruit free of any symptoms), and D, fruit ripening (\% of total fruit) in organic tomato production. Means followed by the same letter within each year are not significantly different $(P<0.05$, least-squares means option of the general linear models procedure of SAS).

Table 3. Main effects of composted cannery wastes on marketable and total yield and fruit ripening in organic tomato production

\begin{tabular}{|c|c|c|c|c|c|}
\hline \multirow[b]{2}{*}{ Compost $(\mathrm{t} / \mathrm{ha})^{\mathrm{x}}$} & \multicolumn{2}{|c|}{ Anthracnose $(\%)^{\mathrm{w}}$} & \multirow{2}{*}{$\begin{array}{l}\text { Marketable } \\
\text { yield (t/ha) }\end{array}$} & \multirow{2}{*}{$\begin{array}{l}\text { Total yield } \\
\text { (t/ha) }\end{array}$} & \multirow{2}{*}{$\begin{array}{c}\text { Ripe } \\
\text { fruit }(\%)\end{array}$} \\
\hline & 1997 & 1998 & & & \\
\hline 0 & $2.0 \mathrm{a}$ & $15.5 \mathrm{a}$ & $38.6 \mathrm{~b}$ & $61.5 \mathrm{~b}$ & $88.3 \mathrm{~b}$ \\
\hline $12-15$ & $1.8 \mathrm{a}$ & $12.9 \mathrm{a}$ & $51.0 \mathrm{a}$ & $70.8 \mathrm{a}$ & $89.1 \mathrm{~b}$ \\
\hline $24-30$ & $2.4 \mathrm{a}$ & $9.0 \mathrm{~b}^{\mathrm{z}}$ & $51.4 \mathrm{a}$ & $72.4 \mathrm{a}$ & $91.6 \mathrm{a}$ \\
\hline
\end{tabular}

${ }^{\mathrm{v}}$ Means followed by the same letter within each year are not significantly different $(P<0.05$, least squares means option of the general linear models procedure of SAS).

${ }^{w}$ Fruit with anthracnose (Colletotrichum coccodes) (\% of total fruit). Means of nontransformed data are presented for clarity.

${ }^{x}$ Compost was applied at 12 and $24 \mathrm{t} / \mathrm{ha}$ in 1997 and 15 and $30 \mathrm{t} / \mathrm{ha}$ in 1998, all on a dry weight basis.

y Total healthy fruit free of any disease symptoms.

${ }^{\text {z }} P=0.07$

formed (natural $\log$ of $[x+0.5]$ ) before further analysis to normalize the data (33). Analysis of variance was performed on two-year combined data by using the general linear model procedure of SAS and means were separated with least squares estimates of marginal means.

\section{RESULTS}

Organic tomato production. The incidence of bacterial diseases (bacterial speck in 1997 and bacterial spot in 1998) occurring naturally in organic tomatoes was low and not affected by the compost amendments (Table 2). In 1997, the incidence of anthracnose was low and not affected by compost amendment. However the high compost amendment rate reduced anthrac- nose incidence $(P=0.07)$ in 1998 , when disease was severe in all plots (Table 3 ). Amendment of soil with composted cannery wastes increased marketable fruit yield by $33 \%$ and total fruit yield by $16 \%$ on average, but there was no difference between the high and low compost amendment rates (Table 3). Plots amended with the high rate of compost had significantly more ripe fruit than control plots or those amended with the low rate of compost. The incidence of anthracnose, as well as the combined incidence of all fruit diseases (total diseased fruit), was less on cv. $\mathrm{OH}$ 8245 than on Peto 696 in 1998 (Fig. 1A and B). In 1997, disease pressure was low and there were no differences in disease incidence among the cultivars. Marketable
Table 4. Effect of cultivar on total fruit yield in the organic plots amended with composted cannery wastes

\begin{tabular}{lcc}
\hline & \multicolumn{2}{c}{ Total yield $(\mathbf{t} / \mathbf{h a})^{\mathbf{y}}$} \\
\cline { 2 - 3 } Compost $(\mathbf{t} / \mathbf{h a})^{\mathbf{z}}$ & Peto 696 & OH 8245 \\
\hline 0 & $68.2 \mathrm{a}$ & $54.9 \mathrm{~b}$ \\
$12-15$ & $69.2 \mathrm{a}$ & $72.5 \mathrm{a}$ \\
$24-30$ & $72.4 \mathrm{a}$ & $72.3 \mathrm{a}$ \\
\hline
\end{tabular}

${ }^{y}$ Total fruit. Means followed by the same letter within each column are not significantly different $(P<0.05$, least squares means option of the general linear models procedure of SAS).

${ }^{z}$ Compost was applied at 12 and $24 \mathrm{t} / \mathrm{ha}$ in 1997 and 15 and 30 t/ha in 1998, all on a dry weight basis.

yields were affected by cultivar. Peto 696 had higher marketable yield each year and a greater proportion of ripe fruit in 1997 than did $\mathrm{OH} 8245$ (Fig. 1C and D). Total fruit yield (marketable plus unmarketable) in the organic plots amended with composted cannery wastes was also affected by cultivar (Table 4). There was a $32 \%$ increase in total fruit yield in compostamended plots with $\mathrm{OH} 8245$, but no differences with Peto 696. None of the disease or yield variables assessed were affected by planting mix used for seedling production, although there was a significant year-planting mix interaction for bacterial disease incidence and compostplanting mix interaction for total yield. 
Table 5. Analyses of variance ANOVA) of foliar area under the disease progress curve (AUDPC), percent bacterial spot and anthracnose on fruit, marketable and total yield, and percent total ripe fruit in conventional tomato production during 1997 and $1998^{2}$

\begin{tabular}{|c|c|c|c|c|c|c|c|}
\hline \multirow[b]{2}{*}{ Source } & \multirow[b]{2}{*}{ df } & \multicolumn{6}{|c|}{ Mean squares } \\
\hline & & $\begin{array}{c}\text { Foliar } \\
\text { AUDPC }\end{array}$ & $\begin{array}{c}\text { Bacterial spot } \\
(\%)\end{array}$ & $\begin{array}{c}\text { Anthracnose } \\
(\%)\end{array}$ & $\begin{array}{c}\text { Marketable } \\
\text { yield }\end{array}$ & $\begin{array}{l}\text { Total } \\
\text { yield }\end{array}$ & $\begin{array}{l}\text { Total ripe } \\
\text { fruit }(\%)\end{array}$ \\
\hline Year & 1 & 129,434 & $1,273.0 * *$ & $309.9 *$ & $8,897.3^{* *}$ & $25,959.1 * *$ & 10.0 \\
\hline Block (year) & 6 & $441,858 * *$ & 18.3 & $161.5^{*}$ & 271.1 & 189.5 & $226.6^{*}$ \\
\hline Compost & 2 & $1,225,090 * *$ & $53.8^{*}$ & 113.3 & 190.7 & 524.6 & 163.5 \\
\hline Year $\times$ compost & 2 & 23,977 & $141.5^{* *}$ & 56.7 & 120.1 & 145.0 & 152.7 \\
\hline Block $\times$ compost (year) & 12 & 145,653 & 12.2 & 64.2 & 273.8 & 281.4 & 98.3 \\
\hline Planting mix & 1 & 82,427 & 32.4 & $253.9 *$ & 93.7 & 1.6 & 42.3 \\
\hline Year $\times$ planting mix & 1 & 72,325 & $124.2 *$ & $297.8^{*}$ & 17.6 & 1.1 & 6.317 \\
\hline Compost $\times$ planting mix & 2 & 15,888 & 20.2 & 131.9 & 222.0 & 129.8 & $780.0 *$ \\
\hline Block $\times$ planting mix (year) & 6 & 51,250 & 18.2 & 30.9 & 160.2 & 166.8 & 48.2 \\
\hline Treatment & 1 & $5,195,447 * *$ & $189.9 * *$ & $1,415.8 * *$ & $2371.3 * *$ & 491.7 & 52.0 \\
\hline Year $\times$ treatment & 1 & $969,423 * *$ & 7.7 & 56.6 & 217.0 & 6.8 & $1,991.7 *$ \\
\hline Compost $\times$ treatment & 2 & $271,717 * *$ & 3.8 & 4.3 & 47.6 & 123.4 & 0.0 \\
\hline Planting mix $\times$ treatment & 1 & 1,047 & 8.7 & 178.6 & 102.4 & 37.0 & 82.7 \\
\hline Compost $\times$ planting mix $\times$ treatment & 2 & 64,339 & 2.6 & 43.9 & 28.9 & 27.8 & 40.9 \\
\hline Error & 55 & 42,730 & 8.1 & 53.8 & 131.3 & 126.8 & 78.7 \\
\hline Coefficient of variation & $\ldots$ & 36.7 & 37.1 & 68.4 & 26.5 & 20.0 & 10.7 \\
\hline
\end{tabular}

${ }^{\mathrm{z}}$ ANOVA was performed on combined 1997 and 1998 data; $*$ and $* *$ represent significant effects at the $P=0.05$ and $P=0.01$ level of probability, respectively.

Table 6. Main effects of composted yard wastes on disease severity and incidence in conventionally produced processing tomatoes

\begin{tabular}{lccc}
\hline & & \multicolumn{2}{c}{$\begin{array}{c}\text { Bacterial spot } \\
\text { on fruit }(\%)^{\mathbf{x}}\end{array}$} \\
\cline { 3 - 4 } Rate (t/ha) $^{\mathbf{y}}$ & AUDPC $^{\mathbf{z}}$ & $\mathbf{1 9 9 7}$ & $\mathbf{1 9 9 8}$ \\
\hline 0 & $338.4 \mathrm{~b}$ & $17.6 \mathrm{a}$ & $2.8 \mathrm{a}$ \\
$25-37$ & $660.3 \mathrm{a}$ & $12.6 \mathrm{~b}$ & $4.3 \mathrm{a}$ \\
$50-74$ & $690.4 \mathrm{a}$ & $11.7 \mathrm{~b}$ & $4.3 \mathrm{a}$ \\
\hline
\end{tabular}

$\mathrm{x}$ Percent bacterial spot on fruit in plots artificially inoculated with Xanthomonas vesicatoria. Means followed by the same letter within each column are not significantly different $(P$ $<0.05$, least squares means option of the general linear models procedure of SAS).

y Compost was applied at 25 and 50 t/ha in 1997 and 37 and 74 t/ha in 1998, all on a dry weight basis.

${ }^{\mathrm{z}}$ Foliar area under the disease progress curve calculated using midpoints (percent foliar disease) of Horsfall-Barratt ratings.

The concentrations of essential nutrients in the foliage of plants grown in plots amended with composts did not differ from those in the foliage of plants grown in nonamended control plots (data not shown). The concentration of foliar $\mathrm{N}$ in these plots ranged from 4.1 to $4.5 \%$. These values are within the recommended range for tomato (27).

Conventional tomato production. Foliar AUDPC values and bacterial spot incidence on fruit were affected by compost amendment, whereas anthracnose incidence, marketable and total fruit yields, and proportion of ripe fruit were not (Table 5). The foliar AUDPC value (percent foliar disease) for compost-amended plots was higher than for the nonamended control (Table 6). Bacterial spot was the predominant foliar disease in 1997, but Septoria leaf spot predominated late in the 1998 season. In 1997, the incidence of bacterial spot on fruit was lower in plots

Table 7. Main effects of planting mix on the incidence of bacterial spot and anthracnose on fruit in conventional tomato production ${ }^{\mathrm{w}}$

\begin{tabular}{lccccc}
\hline & \multicolumn{2}{c}{ Bacterial spot $(\%)^{\mathbf{x}}$} & & \multicolumn{2}{c}{ Anthracnose (\%) } \\
\cline { 2 - 3 } \cline { 5 - 6 } Planting $\mathbf{~ m i x}^{\mathbf{z}}$ & $\mathbf{1 9 9 7}$ & $\mathbf{1 9 9 8}$ & & $\mathbf{1 9 9 7}$ & $\mathbf{1 9 9 8}$ \\
\hline CPB & $9.6 \mathrm{~b}$ & $4.6 \mathrm{a}$ & & $15.9 \mathrm{a}$ & $8.8 \mathrm{a}$ \\
BACCTO & $13.0 \mathrm{a}$ & $3.5 \mathrm{a}$ & & $9.1 \mathrm{~b}$ & $9.1 \mathrm{a}$ \\
\hline
\end{tabular}

${ }^{\mathrm{w}}$ Means followed by the same letter within each year are not significantly different $(P<0.05$, least squares means option of the general linear models procedure of SAS).

${ }^{\mathrm{x}}$ Percent bacterial spot on fruit in plots artificially inoculated with Xanthomonas vesicatoria.

${ }^{y}$ Percent naturally occurring anthracnose (Colletotrichum coccodes) in tomato fruit.

${ }^{\mathrm{z}}$ Tomato transplants were grown either in a CPB mix (composted pine bark amended potting mix inoculated with the biocontrol agents Trichoderma hamatum 382 and Chryseobacterium gleum 299) or BACCTO mix (a standard commercial peat mix).

amended with composted yard wastes than in nonamended control plots (Table $6)$. The low amendment rate was as effective as the high rate. The 1998 season was relatively dry in June and July at the Wooster location, and the incidence of bacterial diseases was very low (Table 6). Significant differences in incidence of bacterial spot on fruit were not observed among compost treatments. The incidence of bacterial spot and anthracnose on fruit was affected by the planting mix in which seedlings were produced (Table 7). In 1997, bacterial spot incidence was less severe and anthracnose was more severe on fruit from tomato originating in composted pine bark-amended potting mix inoculated with the biocontrol agents $T$. hamatum 382 and C. gleum 299. These diseases were not affected by planting mix in 1998 (Table 7). Planting mix affected fruit ripening in conventional plots amended with composted yard wastes (Table 8). Plants resulting from seedlings produced in composted pine bark-amended potting mix yielded significantly more ripe fruit when grown in soil amended with the high rate of compost than in the nonamended control plots. This effect was not observed for plants originating in BACCTO mix. Furthermore, tomato fruit ripened approximately 2 weeks earlier in plots amended with compost than in control plots.

Total foliar disease was lower in Actigard-treated plots than in the control in both 1997 and 1998 (Table 9). Actigard also decreased the incidence of bacterial spot on fruit under the high and low disease pressures that occurred in 1997 and 1998, respectively. Actigard reduced the incidence of anthracnose on fruit compared to the control. Marketable yield was higher in plots treated with Actigard than in the untreated control, even though the proportion of ripe fruit was lower in Actigard-treated plots than in the control (Table 9). Actigard also reduced disease severity in tomato foliage (foliar AUDPC) in nonamended plots and plots amended with the low and high rates of composted yard wastes (Table 10).

Concentrations of essential nutrients in leaves of plants grown in plots treated with compost did not differ from those in leaves collected from control plots (data not shown). The concentrations of foliar $\mathrm{N}$ ranged from 5.0 to $5.6 \%$, which are within the recommended range for tomato. 


\section{DISCUSSION}

The results of this study substantiate an earlier report (36) that composts incorporated into soil can reduce the severity of some aboveground diseases of plants. Although compost amendments increased foliar disease symptoms in this work, disease incidence on fruit was reduced. Bacterial spot and speck incidence was low $(<3 \%$, data not shown) in the organic system, which was located in a farmer's field and consequently was not inoculated. In the conventional, inoculated system, bacterial spot incidence on fruit was reduced in the one year (1997) when disease pressure was high. Tomato plants produced from seedlings grown in compost-amended pine bark mix fortified with the biocontrol agents T. hamatum 382 and C. gleum 299 also had a lower bacterial spot incidence on fruit compared to those produced in standard BACCTO mix. Anthracnose was reduced in organic tomatoes harvested from plots amended with a high rate of cannery waste compost, but no effect of soil amendments on anthracnose incidence was observed in the conventional system where composted yard waste had been applied. Marketable yield was increased by composts in the organic but not in the con-

Table 8. Effects of planting mix on fruit ripening in conventional plots amended with composted yard waste

\begin{tabular}{lcc}
\hline & \multicolumn{2}{c}{ Ripe fruit (\%) } \\
\cline { 2 - 3 } Compost (t/ha) & CPB & BACCTO \\
\hline 0 & $80.2 \mathrm{~b}$ & $81.7 \mathrm{a}$ \\
$25-37$ & $85.0 \mathrm{ab}$ & $81.8 \mathrm{a}$ \\
$50-74$ & $86.6 \mathrm{a}$ & $84.4 \mathrm{a}$ \\
\hline
\end{tabular}

${ }^{\mathrm{y}}$ Percent of total fruit. Tomato transplants were grown either in a CPB mix (composted pine bark amended potting mix inoculated with the biocontrol agents Trichoderma hamatum 382 and Chryseobacterium gleum 299) or BACCTO mix (a standard commercial peat mix). Means followed by the same letter within each year are not significantly different $(P<0.05$, least squares means option of the general linear models procedure of SAS).

${ }^{\mathrm{z}}$ Compost was applied at 25 and $50 \mathrm{t} / \mathrm{ha}$ in 1997 and 37 and 74 t/ha in 1998, all on a dry weight basis. ventional system, but this may have been related to cultivar. $\mathrm{OH} 8245$ was more responsive to compost amendment than was Peto 696, with significantly higher yields in compost-amended than nonamended plots in the organic system. Yield of Peto 696 was not affected by composts in either system.

Compost amendments have been shown to increase the activities of biocontrol agents in the rhizosphere of tomato plants and reduce the severity of diseases caused by soilborne plant pathogens on this crop (3). They improve drainage and water retention of amended soils and release essential nutrients during the growing season at rates required for crop uptake if appropriate amendment rates are utilized (5). These beneficial effects, which affect plant growth and physiology, only occur consistently if composts have been stabilized adequately before their utilization (5). Inadequately stabilized composts can be phytotoxic and therefore delay plant growth and reduce yield (5). All composts used in this study were within the stability range required for beneficial utilization (18) and all stimulated growth of tomato plants on treated plots over the control in both years at each location (unpublished observations).

Table 10. Effect of foliar applications of Actigard on disease severity in foliage (area under the disease progress curve; AUDPC) in conventional plots amended with composted yard wastes $^{\mathrm{x}}$

\begin{tabular}{lccc}
\hline & \multicolumn{3}{c}{ Foliar AUDPC $^{\mathbf{y}}$} \\
\cline { 2 - 4 } Treatment $^{\mathbf{z}}$ & $\mathbf{0}$ & Low & High \\
\hline Control & $467 \mathrm{a}$ & $941 \mathrm{a}$ & $982 \mathrm{a}$ \\
Actigard & $210 \mathrm{~b}$ & $380 \mathrm{~b}$ & $405 \mathrm{~b}$ \\
\hline
\end{tabular}

x AUDPC calculated using midpoints (percent foliar disease) of Horsfall-Barratt ratings.

y Plots amended with composted yard waste. Compost was applied at 25 and $50 \mathrm{t} / \mathrm{ha}$ in 1997 and 37 and 74 t/ha in 1998 (dry weight basis). Means followed by the same letter within each column are not significantly different $(P<0.05$, least squares means option of the general linear models procedure of SAS).

${ }^{\mathrm{z}}$ Treatment consisted of 12 foliar applications of Actigard at 7- to 10-day intervals.
In the conventional plots, care was taken to minimize differences in availability of essential plant nutrients by adjusting the low compost loading rate so as to supply all nutrients required for the tomato crop while supplying equivalent concentrations of mineral nutrients as fertilizers to control plots. Foliar analyses confirmed that this was indeed accomplished in both years. Thus, it is unlikely that the results observed were related to nutrient effects.

We observed that tomato plants in both organic and conventional trials in compostamended plots were larger in the first 4 weeks after transplanting than those in control plots (unpublished observations). In the organic trial, which received no supplemental irrigation, compost amendments may have contributed to increased growth and yield by improving the waterholding capacity of soil and allowing faster plant establishment, particularly in 1998 when June and July were unusually dry. This agrees with published accounts on such effects of composts incorporated into soils on plant growth (8). However, plant growth-promoting microorganisms and biocontrol agents that are stimulated in the rhizosphere by compost amendments (3) probably also contributed.

The mechanism by which composts incorporated into field soil may reduce the severity of bacterial diseases and anthracnose on fruit, while apparently increasing the severity of foliar diseases, remains unknown. Resistance was induced to both foliar and fruit diseases by the synthetic plant activator Actigard, confirming the results of a recent multiregional study demonstrating the effectiveness of this product in reducing bacterial spot and bacterial speck in tomato (21). It is possible that the effects observed on fruit in compost-amended soils might have been due to systemic induced resistance, but that the effect, if present, was relatively shortlived. Thus, green fruit in compostamended plots may have been less susceptible initially to $X$. vesicatoria and $C$. coccodes than those in nonamended plots. Later in the season, when disease pressure from foliar pathogens was high, the effect of composts may have been di-

Table 9. Main effects of foliar sprays with Actigard on disease severity (area under the disease progress curve; AUDPC) in foliage, incidence on fruit, marketable yield, and fruit ripening in conventionally produced tomatoes ${ }^{t}$

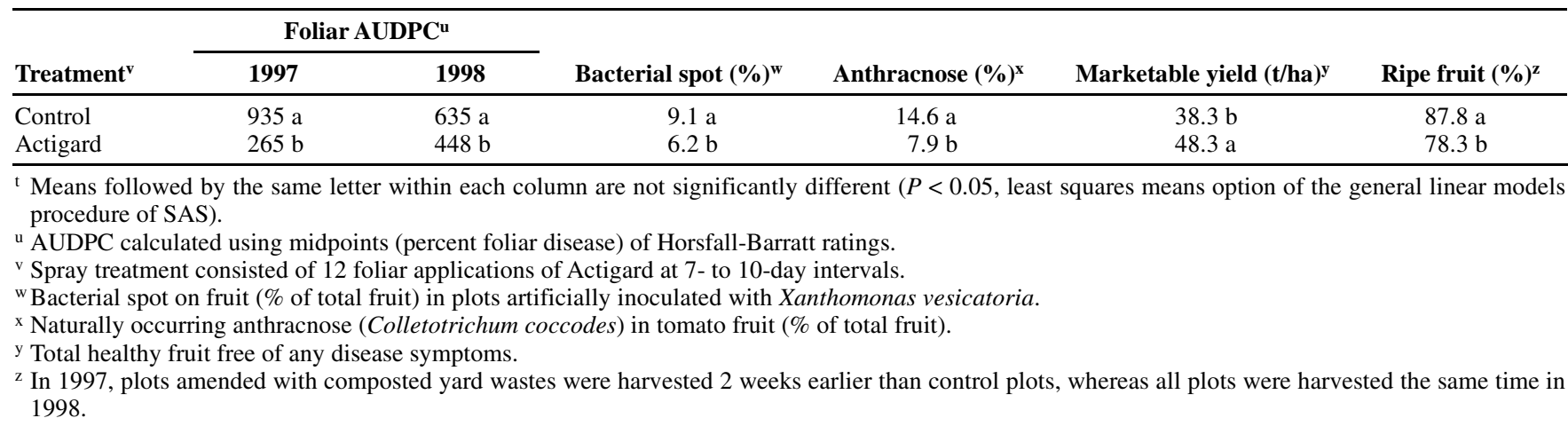


minished, allowing more foliage to become infected. In both years, foliar disease was not significant in any plots until early August, while the first $X$. vesicatoria inoculation was made at least 4 weeks earlier, when green fruit were already present. Possibly, therefore, the suppressive effects induced by the composts against the foliar disease declined during the season as the organic matter sustaining this effect decomposed. Stone et al. (35) demonstrated the transitory nature of the suppressive effect induced by composted cow manure against Pythium damping-off. The same may apply to systemic effects against foliar diseases.

We conclude that compost amendments can play an important role in reducing economic losses from diseases to tomato growers, especially in organic production systems where the production of healthier fruit and increased yield were demonstrated. Numerous compost quality parameters must be considered to provide consistent effects against root diseases (14). Consistent control of foliar and fruit diseases may prove equally, if not even more, challenging.

\section{ACKNOWLEDGMENTS}

We thank L. V. Madden, OSU Department of Plant Pathology, for advice on statistical analyses; M. E. Watson, OSU School of Natural Resources, for advice on fertility aspects of compost and soils; D. Francis and M. Bennett, OSU Department of Horticulture and Crop Science, for reviewing this manuscript; Hirzel Farms (Luckey, OH), Kurtz Brothers (Independence, $\mathrm{OH}$ ), and Syngenta Crop Protection (Greensboro, NC); and the late J. Hirzel, Hirzel Farms, whose enthusiasm, dedication to research, and cooperation were critical to the project.

\section{LITERATURE CITED}

1. Abbasi, P. A, Sahin, F., Hoitink, H. A. J., and Miller, S. A. 1997. Induction of systemic resistance against bacterial spot in tomato seedlings by compost-amended substrates and Actigard. (Abstr.) Phytopathology 87:2.

2. Adaskaveg, J. E., and Hine, R. B. 1985. Copper tolerance and zinc sensitivity of Mexican strains of Xanthomonas campestris pv. vesicatoria, causal agent of bacterial spot of pepper. Plant Dis. 69:993-996.

3. Alvarez, M. A., Gagné, S., and Antoun, H. 1995. Effect of compost on rhizosphere microflora of the tomato and on the incidence of plant growth-promoting rhizobacteria. Appl. Environ. Microbiol. 61:194-199.

4. Chellemi, D. O., Mitchell, D. J., and Barkdol, A. W. 1992. Effect of composted organic amendments on the incidence of bacterial wilt of tomato. Proc. Fla. State Hortic. Soc. 105:364-366.

5. Chen, Y., and Inbar, Y. 1993. Chemical and spectroscopical analyses of organic matter transformations during composting in relation to compost maturity. In: Science and Engineering of Composting: Design, Environmental, Microbiological, and Utilization Aspects. H. A. J. Hoitink and H. M. Keener, eds. Renaissance Publications, Worthington, $\mathrm{OH}$.

6. Dick, W. A., and McCoy, E. L. 1993. Enhancing soil fertility by addition of compost. Pages 622-644 in: Science and Engineering of
Composting: Design, Environmental, Microbiological, and Utilization Aspects. H. A. J. Hoitink and H. M. Keener, eds. Renaissance Publications, Worthington, $\mathrm{OH}$

7. Epstein, E., Taylor, J. M., and Chaney, R. L. 1976. Effects of sewage sludge compost applied to soil physical and chemical properties. J. Environ. Qual. 5:422-426.

8. Gamliel, A., and Stapleton, J. J. 1993. Effect of chicken compost or ammonium phosphate and solarization on pathogen control, rhizosphere microorganism, and lettuce growth. Plant Dis. 77:886-891.

9. Gleason, M. L., McNab, A. A., Pitblado, R. E., Ricker, M. D., Eastbourne, D. A., and Latin, R. X. 1995. Disease warning systems for processing tomatoes: are we there yet? Plant Dis. 79:113-121.

10. Görlach, J., Volrath, S., Knauf-Beiter, G., Beckhove, U., Kogel, K-H., Oostendorp, M., Staub, T., Ward, E., Kessmann, H., and Ryals, J. 1996. Benzothiadiazole, a novel class of inducers of systemic acquired resistance, activates gene expression and disease resistance in Wheat. Plant Cell 8:629-643.

11. Grebus, M. E., Watson, M. E., and Hoitink, H. A. J. 1994. Biological, chemical and physical properties of composted yard trimmings as indicators of maturity and plant disease suppression. Compost Sci. Util. 2:57-71.

12. Han, D. Y., Coplin, D. L., Bauer, W. D., and Hoitink, H. A. J. 2000. A rapid bioassay for screening rhizosphere microorganisms for their ability to induce systemic resistance. Phytopathology 90:327-332.

13. Hardy, G. E. St. J., and Sivasithamparam, K. 1991. Suppression of Phytophthora root rot by a composted Eucalyptus bark mix. Aust. J. Bot. 39:153-159.

14. Hoitink, H. A. J., and Boehm, M. J. 1999. Biocontrol within the context of soil microbial communities: a substrate-dependent phenomenon. Annu. Rev. Phytopathol. 37:427-446.

15. Hoitink, H. A. J., and Fahy, P. C. 1986. Basis for the control of soilborne plant pathogens with composts. Annu. Rev. Phytopathol. 24:93-114.

16. Hoitink, H. A. J., Inbar, Y., and Boehm, M. J. 1991. Status of compost-amended potting mixes naturally suppressive to soilborne diseases of floricultural crops. Plant Dis. 75:869873.

17. Horsfall, J. G., and Barratt, R. W. 1945. An improved grading system for measuring plant diseases. (Abstr.) Phytopathology 35:655.

18. Iannotti, D. A., Grebus, M. E., Toth, B. L., Madden, L. V., and Hoitink, H. A. J. 1994. Oxygen respirometry to assess stability and maturity of composted municipal solid waste. J. Environ. Qual. 23:1177-1183.

19. Khaleel, R., Reddy, K. R., and Overcash, M. R. 1981. Changes in soil physical properties due to organic waste application: A review. J. Environ. Qual. 10:133-141

20. Kwok, O. C. H., Fahy, P. C., Hoitink, H. A. J., and Kutter, G. A. 1987. Interactions between bacteria and Trichoderma hamatum in suppression of Rhizoctonia damping-off in bark compost media. Phytopathology 77:1206-1212.

21. Louws, F. J., Wilson, M., Campbell, H. L., Cuppels, D. A., Jones, J. B., Shoemaker, P. B., Sahin, F., and Miller, S. A. 2001. Field control of bacterial spot and bacterial speck of tomato using a plant activator. Plant Dis. 85:481-488.

22. Lumsden, R. D., Lewis, J. A., and Millner, P. D. 1983. Effect of composted sewage sludge on several soilborne pathogens and diseases. Phytopathology 73:1543-1548.

23. Maynard, A. A. 1994. Sustained vegetable production for three years using composted animal manures. Compost Sci. Util. 2:88-96.

24. Meek, B., Graham, L., and Donovan, T. 1982. Long-term effects of manure on soil nitrogen, phosphorus, potassium, sodium, organic matter, and water infiltration rate. Soil Sci. Soc. Am. J. 46:1014-1019.

25. Miller, S. A., Sahin, F, Krause, M., AlDahmani, J., Stone, A., and Hoitink, H. A. J. 1997. Control of bacterial leaf spot of radish in compost-amended planting mixes. (Abstr.) Phytopathology 87:66.

26. Ndayegamiye, A., and Cote, D. 1989. Effect of long-term pig slurry and solid cattle manure application on soil chemical and biological properties. Can. J. Soil Sci. 69:3947.

27. Precheur, R. J., ed. 2000. Ohio Vegetable Production Guide. The Ohio State Univ. Ext. Bull. 672.

28. Quarles, W., and Grossman, J. 1995. Alternatives to methyl bromide in nurseries- Disease suppressive media. IPM Practitioner 17:1-13.

29. Ritchie, D. F., and Dittapongpitch, V. 1991. Copper- and streptomycin-resistant strains and host differential races of Xanthomonas campestris pv. vesicatoria in North Carolina. Plant Dis. 75:733-736.

30. Ryals, J., Uknes, S., and Ward, E. 1994. Systemic acquired resistance. Plant Physiol. 104:1109-1112.

31. Sahin, F., and Miller, S. A. 1995. Characterization of Ohio strains of Xanthomonas campestris pv. vesicatoria causal agent of bacterial spot of pepper. Plant Dis. 80:773-778.

32. Schüler, C., Pikny, J., Nasir, M., and Vogtmann, H. 1993. Effects of composted organic kitchen and garden waste on Mycosphaerella pinodes (Berk. et Blox) Vestergr., causal organism of foot rot on peas (Pisum sativum L.). Biol. Agric. Hortic. 9:353-360

33. Steel, R. J. D., Torrie, J. H., and Dickey, D. A. 1997. Principles and Procedures of Statistics: A Biometrical Approach. 3rd ed. McGraw Hill Book Co., New York.

34. Sticher, L., Mauch-Mani, B., and Métraux , J. P. 1997. Systemic acquired resistance. Annu. Rev. Phytopathol. 35:235-270.

35. Stone, A G., Traina, S. J., and Hoitink, H. A. J. 2001. Particulate organic matter composition and Pythium damping-off of cucumber. Soil Sci. Soc. Am. J. 65:761-770.

36. Tränkner, A. 1992. Use of agricultural and municipal organic wastes to develop suppressiveness to plant pathogens. Pages $35-42$ in: Biological Control of Plant Diseases. E. C. Tjamos, G. C. Papavizas, and R. J. Cook, eds. Plenum Press, New York.

37. Workneh, F., and van Bruggen, A. H. C. 1994 Suppression of corky root of tomatoes in organically managed soil associated with soil microbial activity and nitrogen status of soil and tomato tissue. Phytopathology 81:688694.

38. Workneh, F., and van Bruggen, A. H. C. 1994 Microbial density, composition, and diversity in organically and conventionally managed rhizosphere soil in relation to suppression of corky root of tomatoes. Appl. Soil Ecol. $1: 219-230$.

39. Zhang, W., Han, D. Y., Dick, W. A., Davis, K. R., and Hoitink, H. A. J. 1998. Compost and compost water extract-induced systemic acquired resistance in cucumber and Arabidopsis. Phytopathology 88:450-455.

40. Zhang, W., Hoitink, H. A. J., and Dick, W. A. 1996. Compost-induced systemic acquired resistance in cucumber to Pythium root rot and anthracnose. Phytopathology 86:1066-1070. 